Article

\title{
Livelihood Trajectories in a Context of Repeated Displacement: Empirical Evidence from Rwanda
}

\author{
Ine Cottyn
}

International Development Studies, Department of Human Geography and Planning, University of Utrecht, 3584CB Utrecht, The Netherlands; inecottyn@gmail.com; Tel.: +31-612794806

Received: 17 August 2018; Accepted: 27 September 2018; Published: 30 September 2018

\begin{abstract}
Displacement, forced migration, and resettlement in Africa have been attributed to a variety of causes and is disrupting all aspects of people's lives, breaking social, cultural and economic networks that are critical to sustaining livelihoods. Rwanda is one of the countries in Africa with a long history of multiple displacements, and the life trajectories of many Rwandans are characterised by multiple experiences of displacement, and involuntary migration. Although many have researched the effects of displacement on people's livelihoods from both an academic, as well as a practitioner's viewpoint, less is known about the effects of multiple and repeated displacements over time on people's livelihood. Instead of treating each displacement separately, this article aims to analyse the effects of repeated displacement the livelihoods and adaptive capacity of households in Rwanda. To this purpose, six months of fieldwork were conducted in the north-western region of Rwanda, collecting data from a household livelihood survey, household livelihood and mobility histories, and focus group discussions. The research highlights the importance of social and human capital as crucial to people's resilience. However, the successive loss of natural capital in combination with changing social and economic conditions diminishes the ability of many households to keep employing these capitals to reconstruct a sustainable livelihood. Forced to become increasingly creative and flexible in their coping strategies, many households employ mobility as a survival mechanism to spread risks.
\end{abstract}

Keywords: Rwanda; displacement; resettlement; livelihood; adaptive capacity; mobility

\section{Introduction}

Africa is a continent on the move. It experiences all possible migratory configurations, from labour migration to refugee flows and displacements. While international political and policy attention mainly focuses on the flows of migrants and refugees into Europe, the majority move within the continent and even within the own country as a result of forced displacement. Africa has more countries affected by displacement than any other continent or region: In 2016, more than 3.9 million new displacements resulting from conflict, violence and disasters were recorded [1]. Displacement, forced migration and resettlement in Africa have been attributed to violent conflict, land and agrarian reforms, forced resettlement, environmental hazards and conservation measures [2]. Displacement disrupts all aspects of people's lives, breaking social, cultural and economic networks that are critical to sustaining livelihoods, income, land ownership and household income. Although those who are affected by these forces are generally considered victims, this does not mean that they lack the agency to act upon them and respond to different forms of enforcements. The specificities of each context affect the conditions of possibility for lives and livelihoods, and for patterns of inclusion and exclusion [3]. There are a lot of studies of displacement and resettlement with a livelihoods approach, from both an academic, as well as a practitioner's viewpoint. Livelihood studies have been undertaken in response to conflict $[4,5]$, state-implemented resettlement schemes $[6,7]$ or natural hazards and climate change 
adaptation $[7,8]$. However, while most studies typically look at only one displacement or an event attributed to only one cause, less is known about the effects of multiple and repeated displacements over time on people's livelihoods.

Rwanda's history is characterised by patterns of both voluntary mobility and multiple displacements, resulting from the many episodes of violent conflicts the country has faced in the past, and more recently from its post-conflict human settlement policies and environment-related policies. Consequently, the life trajectories of many Rwandans are characterised by multiple experiences of displacement and involuntary migration. Instead of treating each displacement separately, this article aims to analyse the effects of repeated displacement on people's livelihood and adaptive capacity. In order to do so, the article provides empirical evidence of one case study in Rwanda's north-western region where people share experiences of repeated displacement and resettlement over time caused by conflict, settlement policies and environmental and climate change adaptation policies.

The following section presents an overview of the methodology used to collect the data, followed by a brief review of the literature on displacement and livelihood. Section 4 provides the context of this article by discussing the historical patterns of voluntary mobility and multiple displacements that have affected Rwandan society. Sections 5-7 tell the stories of three local households to illustrate the shared experiences of displacements and resettlements in the village, as well as the varied trajectories in terms of livelihood reconstruction and resilience. Section 8 presents a final conclusion.

\section{Methodology}

The article draws on data collected within a broader research on rural-urban connections, rural transformation and mobility in Rwanda (this research took place within the framework of the RurbanAfrica project, funded by the European Union under the 7th Research Framework Programme http:/ / rurbanafrica.ku.dk/). The empirical data presented in this article is collected in one selected location in the northwest part of Rwanda in 2014. The data were derived from a household livelihood survey, household livelihood and mobility histories, and focus group discussions. The case study location was selected as part of the larger research framework, on the basis of the different dynamics at play in terms of demographics and mobility patterns, agricultural transformations, and options for economic diversification. In terms of data collection, a three-stage approach was opted for. First, 85 households participated in a rural livelihood household survey, collecting data on household characteristics, migration and mobility, agriculture and livestock, different assets and expenditures. This was followed by three focus group discussions of each ten participants with both youth and heads of household, whereby both rural transformation and its relation to mobility and migration was discussed. The data from survey and the focus group discussions provided an insight into the general picture of the village, revealing the history of multiple displacements that the households in this village shared. The main source of data for this article however, stems from the livelihood-mobility histories. Based on these findings, ten households were selected to conduct livelihood-mobility histories. This method concerns an adaptation of the classic life history, however focusing specifically on how the livelihoods of the households have changed over time in terms of activity and mobility. A life history approach has proven to be a fitting method when social change and social mobility are under investigation and the impact of political and economic change or development on the lives of individuals and households. It explores people's decisions across different geographical, historical, socio-economic and temporal contexts. This methodology is particularly relevant in studying the dynamic character of people's livelihood trajectories and mobility narratives by considering both social and geographical mobility. In Table 1, below, the demographic characteristics of the ten respondents who participated in the livelihood-mobility histories are outlined, as well as their shared displacement history. 
Table 1. Household characteristics and history of displacement and resettlement.

\begin{tabular}{|c|c|c|c|c|c|c|c|c|}
\hline & $\begin{array}{l}\text { Year of } \\
\text { Birth }\end{array}$ & $\begin{array}{l}\text { Number } \\
\text { of HH } \\
\text { Members }\end{array}$ & $\begin{array}{c}\text { Female } \\
\text { Headed } \\
\text { HH }\end{array}$ & $\begin{array}{l}\text { Moved } \\
\text { to DRC }{ }^{1}\end{array}$ & $\begin{array}{l}\text { Moved } \\
\text { Back to } \\
\text { Rwanda }\end{array}$ & $\begin{array}{l}\text { Moved } \\
\text { to } \\
\text { Gishwatti }\end{array}$ & $\begin{array}{l}\text { Resettled in } \\
\text { the Research } \\
\text { Location }\end{array}$ & Current Sources of Income \\
\hline 1 & 1953 & 6 & & 1941 & 1996 & 1999 & 2000 & $\begin{array}{l}\text { - herding livestock } \\
\text { - farming } \\
\text { - selling milk } \\
\text { - remittances }\end{array}$ \\
\hline 2 & 1953 & 3 & $x$ & 1959 & $1994^{2}$ & - & 1998 & - farm wage labour \\
\hline 3 & 1951 & 9 & & 1960 & 1995 & 1998 & 2000 & $\begin{array}{l}\text { - farming } \\
\text { - small business }\end{array}$ \\
\hline 4 & 1926 & 4 & & 1959 & 1994 & 1998 & 2003 & $\begin{array}{l}\text { - herding livestock } \\
\text { - wage labour }\end{array}$ \\
\hline 5 & 1975 & 5 & & 1959 & 1996 & 1998 & 2002 & $\begin{array}{l}\text { - farming } \\
\text { - herding livestock }\end{array}$ \\
\hline 6 & 1976 & 5 & $x$ & $1994^{3}$ & 1994 & - & 2003 & $\begin{array}{l}\text { - farming } \\
\text { - wage labour } \\
\text { - cleaner at the health centre }\end{array}$ \\
\hline 7 & 1944 & 6 & & 1946 & 1994 & 1995 & 2000 & $\begin{array}{l}\text { - milk business } \\
\text { - farming }\end{array}$ \\
\hline 8 & 1970 & 5 & $x$ & 1959 & 1994 & 1994 & 2008 & $\begin{array}{l}\text { - farming } \\
\text { - livestock } \\
\text { - remittances }\end{array}$ \\
\hline 9 & 1953 & 4 & $\mathrm{x}$ & 1950 & 1996 & 1998 & 1999 & $\begin{array}{l}\text { - farming } \\
\text { - small trade } \\
\text { - sorghum business }\end{array}$ \\
\hline 10 & 1930 & 2 & & 1950 & 1995 & 1998 & 2000 & $\begin{array}{l}\text { - farming } \\
\text { - remittances }\end{array}$ \\
\hline
\end{tabular}

\section{Displacement, Resettlement and Adaptive Capacity}

The operational concept of displacement was developed after the Second World War to refer exclusively to refugees. The focus on refugees meant that the much wider range of forms of and people affected by displacement-such as forced resettlements by government policies, projects of states and private corporations, natural hazards, etc.-were overlooked. In her book on displacement economies in Africa, Hammar [3] points to the paradoxes of displacement, as it entails experiences of dislocation and movement and of confinement and stuckness, and opportunities, as well as impossibility, destruction, and creativity. These are unevenly experienced by the affected actors and produce or reproduce social, economic and physical spaces, relations and practices. As a relational concept, Hammar [3] (p. 9) defines displacement as "enforced changes in interweaving spatial, social and symbolic conditions and relations".

A livelihood approach is a useful concept considering the impacts of a disaster or disruptive event, since it helps to describe how people draw on and transform assets or resources to cope with these sources off stress [8]. Households construct their livelihoods within a broader socio-economic and physical context using all sorts of social and material assets [9,10]. Five types of capital assets (natural, human, social, physical and financial capital) stand central to the livelihood approach, which households combine and transform in different ways in order to build a livelihood for themselves [6]. These strategies and their outcomes are in turn influenced by policies and institutions that define the context in which people are creating and recreating their livelihoods. The effects of displacement on people's livelihoods and livelihood resilience have been studied in a variety of contexts and locations, looking at violent conflict, development-induced displacement or the effects of climate change $[5,6,11,12]$. These studies see displacement as a shock to the livelihood capital stock of households, followed by new capital accumulation strategies by the displaced households. Without resettlement and livelihood planning aid, this usually leads to an overall decline in living 
conditions and wellbeing $[6,8,13,14]$. Many of these studies focus on the importance of access to assets, such as natural capital, which deprivation is often more strongly affecting the poorer and vulnerable households who mainly rely on common property resources like forests, rivers, fields, and grazing grounds for their livelihoods [11]. Others, stress the dimension of involuntary displacement as a removal from social capital, for example in the form of kinship links or associations $[6,15,16]$. Most of these studies however, look at the effects of one particular displacement or event. While some researchers investigate the impacts of protracted displacement on the livelihood resilience of the displaced, for example caused by sustained conflict in the Great Lakes Region $[17,18]$, less has been done to analyse the effects of multiple and repeated displacements over time on people's livelihoods.

The way people cope with and recover from disruptive events depends on what compelled the changes, and who is affected by them and in what ways. The specificities of each context affect the conditions of and possibilities for livelihood restoration, and the adaptive strategies of those affected $[3,19]$. The adaptive capacity of the individuals and households affected is determined by the pool of assets and resources they can mobilise and diversify their income [20,21]. The term adaptive capacity is often used interchangeably with the term resilience, and in relation to livelihoods refers to the ability to cope with and recover from such pressures, and to maintain or even enhance assets and income under adverse conditions [21,22]. Some households possess more adaptive capacity given their better access to capital while others remain vulnerable, because they are constrained in accessing resources [23].

The focus lies on strengths rather than deficits in order to identify and understand the risk and protective factors that affect the ability to overcome adversity. Risk factors are conditions that lead to decreased livelihood outcomes, while protective factors are the skills, resources, support and coping strategies that increase the likelihood of positive livelihood outcomes and of dealing more effectively with stressful or disruptive events [3] (p. 4). Linking livelihood approaches to resilience thinking can enhance the understanding of livelihood dynamics, putting people, their capabilities to cope with shocks and improve their adaptive capacity at the centre of analysis [21].

\section{Mobility and Displacement: The Rwandan Context}

Rwanda's history is characterised by patterns of both voluntary mobility and multiple displacements changing the country's social, cultural and economic landscape. In response to forced labour movement during colonial times and the ethnic violence at the end of the 1950s, when the country made the transition from a Belgian colony with a Tutsi monarchy to a Hutu-dominated republic (also referred to as the 'Rwandan Revolution' or 'Social Revolution'), many Rwandans fled to neighbouring countries. Refugees who fled Rwanda between 1959 and 1973 are generally referred to as 'old caseload refugees'. Protracted eruptions of violence led to further displacements until the 1994 genocide, which left up to two million people displaced both outside and inside the country. After the genocide, Rwanda continued to suffer repeated waves of displacement and resettlement. Old caseload refugees started entering Rwanda again, often after more than 30 years of exile, as 'new caseload refugees' fled the country.'New caseload refugees' refers to those who fled Rwanda in 1994).

In the aftermath of the Rwandan genocide, around 1 million old caseload refugees returned to Rwanda and had to be given a place to settle. As declared by the Arusha Peace Agreement, returnees whose mother tongue was Kinyarwanda were given citizenship and a place to settle [24] (p. 99). At first, there was no housing problem for these returnees, as by the end of the genocide many new caseload refugees had fled the country, leaving behind empty houses and land. After 1996, these refugees were repatriated and land needed to be shared. The Imidugudu programme ('villagization') was introduced to relocate new and old caseload refugees. It was then used as a security measure to cope with an insurgency in Rwanda's north-western region in 1997-1998. In the end, it became the country's guiding spatial planning policy. The policy still regulates people's settlement options today, relocating all Rwandans living in scattered homesteads to government-created villages. The effects of this resettlement policy have been commented on both positively-claiming higher security-and negatively, pointing at the level of coercion that was applied by the government 
and the effects on people's access to land and basic services, which was promised but often not delivered [25]. Displacement in Rwanda is not only a thing of the past: Although the impact of past displacements continues to be felt in society, Rwandans are still subject to various forms of relocation. These relocations often remain invisible, since they are officially not regarded as involuntary.

The process of relocation described above is seen by some as a new phase of displacement, while others (e.g., the UNHCR) regard it as permanent resettlement, which ends these people's status as being displaced [26]. Although many rural households who moved because of the resettlement policy are no longer counted as displaced, they remain a particularly vulnerable group as new drivers of displacement emerge, such as environmental concerns. Natural hazards and the consequences of climate change are threatening rural people's lives and livelihoods, especially in the hilly landscape in the northwest of the country, forcing many to move. In 2018, landslides caused by heavy rains killed 200 people in Rwanda's northern and western province [27]. Climate change and the environment are considered crucial issues in the government's Vision 2020 development programme, which has led to their prominence on the political agenda [24]. The government's environmental concerns were translated into environmental and climate change adaptation policies, leading to the resettlement of many rural households in affected areas. The Gishwati forest area was one of the places selected for the resettlement of returnees, and a large part of the forest was cleared for this purpose. Many of the people who settled there were Tutsi refugees who had left the country during the previous 40 years. They had returned to Rwanda in 1994 and were assigned a plot of land. The rapid clearing of the forest area and the resulting environmental hazards led the government to introduce policies that forced people out of the forest to conserve and reforest the area [24]. People had to move into grouped settlements assigned by the villagization programme.

As this short historical account illustrates, many Rwandans' life trajectories are characterised by multiple experiences of displacement. The empirical part of this article looks at one particular case study where households experience different, repeated displacements and resettlements.

\section{A Shared History of Displacement and Enforced Resettlement}

The case study in this article concerns a village in the hills of Nyabihu district, bordering Gishwati forest. It is a fairly remote village that is accessible only by motorbike or $4 \times 4$ from the surrounding main service centres. Around the village are very large grazing fields and small plots of land. There are also some small shops and people produce and sell milk and cheese (there is a fromagerie-a cheese factory). The stories of Gaspard, Celestin and Mary (all names in this article have been changed) in the boxes below (Boxes 1-3) illustrate the experiences in terms of displacements that many households in the village share. In many cases, rapid adaptive strategies were needed to cope with these repeated relocations that entailed a changing social, economic and even political environment. The stories in the boxes below are analysed and discussed in Section 5 .

Box 1. Gaspard.

Gaspard was born in 1926 in Rwanda's western province. His parents were farmers and had a large herd of cows. In 1959, at the start of the 'Rwandan Revolution', the family left everything behind and moved to the Democratic Republic of the Congo to start over. In Congo he met Verène, whom he married in 1973. She, too, was born in the western province, in 1950. Her parents were also born there; they were coffee farmers, at a time when there was no monetary economy and people bartered goods. They also kept livestock. When Verène was 9 , she and her family migrated to the DRC, leaving all their cows behind in Rwanda. In Congo, Gaspard and Verène lived in a house belonging to their employer, a farmer; the women worked in the fields and the men herded his cows as wage labourers. Later on, they got some plots of land in lease-lend, on which they farmed. By then Gaspard had also bought some cows of his own. In 1994 they came back to Rwanda and again had to leave behind everything they had. They lived in Musanze for two months and then moved on to the eastern province, where many plots were unused since the owners had fled to Tanzania. The sector officer 
Box 1. Cont.

told them they could use these properties until the owners came back. According to Verène, they never felt they were considered refugees when they lived in the eastern province. They spent almost four years there, until the owners returned in 1998. First the houses were shared between the returned owners and the occupants, who were required to share the land and the harvest. This situation was not sustainable and again they had to leave the land behind and move, this time to the refugee camp near Bigogwe, western province. Since they did not own any land or have any money or a business, they and other refugees decided to move closer to Gishwati forest. They cleared plots of land and grew potatoes, which proved to be a very profitable activity and they were thus able to buy many cows. In 2001, however, the bourgemestre (mayor under the previous administrative system) told them they had to leave the forest. To make people leave their fields they were told that if they continued farming there, they would suffer many diseases. By 2003, all the land had been officially reclaimed by the state. This is when they moved to the village. The redistribution of arable and grazing land did not happen until 2013, so again Gaspard and Verène had to depend on wage labour for their survival. They had to sell many cows to survive that period. Today, the household income can hardly cover their basic needs. Gaspard is now too old to help in the household, while Verène is disabled and can only take care of some household duties. Of their six children, only two are not yet married and contribute to the household income. The daughter who still lives at home moves around in search of wage labour, digging terraces or selling milk for richer households in the village. Their unmarried son had decided to move to Kigali and was currently living there. Although he does not have a permanent job, he sends some money home whenever he can.

(Interview with Gaspard, 13 May 2014)

Box 2. Celestin.

Celestin was born in 1953 in Congo after his parents, who were born in Nyabihu district, had fled there in 1941. In 1976, Celestin married Floride, a Rwandan who was also born in the DRC, in 1958. In Congo they farmed large plots of land and kept livestock. They owned around 30 cows. In 1996, Celestin and Floride were repatriated to Rwanda, which resulted in the loss of all their cows. They took up residence in a small settlement in Nyabihu district in the house of a new caseload refugee. They used the land for farming and bought five new cows. During the 1996-1998 civil war, however, most of their cows were killed and the house was burned down by the FDLR (Forces démocratiques de libération du Rwanda, an armed Hutu rebel group). As a consequence, the household moved to Mukamira trade centre. They could not farm there, so they set up a beer-selling business. As old caseload refugees, in 1999 the government assigned them farmland in Gishwati forest, and they started to farm again. Their relative prosperity was short lived, however, as the combination of Imidugudu and environmental policies forced them to move away again in 2000. Floride and the children moved to the village, while Celestin stayed behind to take care of their livestock and farmland. More cases are registered of people circumventing the government's prohibition of land use during this period, for example by tending to their fields at night [24] (p. 101). (In 2009, Celestin joined his family after the government had confiscated the plots of land to redistribute them amongst the community. Until they got some plots back in 2014, Celestin and his family had to find wage labour opportunities to sustain their livelihood. During those years, Celestin sold many of his cows and today he has only three left. Apart from selling the calves he gets from his three cows, he farms the eight small plots he got back, which are a two-hour walk from his current house. Since then, he has seen the income in his household decrease drastically. They used to grow Irish potatoes and beans that they sold at the market and used as subsistence, but today he has to grow crops prescribed under the new National Agricultural Policy (2004) on a much smaller plot of land. Celestin says he could not be bothered to walk the two hours to his land, since there is so little of it. He now sends wage workers there, but has stopped considering farming as a real activity for himself. Of his seven children, one helps him to take care of the livestock and his daughter, Alliance, takes milk to Rubavu to sell. To supplement the household income, they sometimes get remittances in the form of food from friends and family.

(Interview with Celestin, 12 May 2014) 
Box 3. Mary.

\begin{abstract}
Mary was born in Congo in 1970, in the Masisi refugee camp. Her parents were also born there. Her father worked at a tea company and her mother farmed, kept livestock (including a lot of cows) and had her own sorghum beer business. Today, her father still has plots of land in Congo, but she can longer use them since they are located in an insecure area. Mary left her parents' household in 1985 when she got married. She followed in the entrepreneurial footsteps of her mother and a year later started her own sorghum beer and agricultural produce business. Her husband kept cows. In Congo, they own a lot of plots and livestock, but had to leave everything behind when they were chased back to Rwanda in 1994. Mary recounted how it was very hard to start a new life from nothing. They struggled to adapt to the miserable conditions they ended up in, but little by little they recovered through the sorghum beer business she had started with the help of her sister. Then, the 1998 war came along. Mary's house was burned down and for two years she had no income, which she said was the worst period of her life. These repeated eruptions of violence destroyed the economic status of her household. After she got about 15 plots of land in Gishwati forest, the household income recovered again. Her luck was short lived, however, as in 2008 she had to move out of the forest as a consequence of the government's resettlement scheme. Again, her livelihood was disrupted, until she got some plots back in 2013. However, the plots are a lot smaller than the ones she used to have. Yet again she managed to recover through the income of her sorghum beer business. She bought a plot of land and built a house, and now cultivates a tiny plot of land, owns two cows and continues to run her small sorghum beer business. She managed to get a RWF 300,000 (around USD 346) loan from a Umurenge SACCO (savings and credit cooperative) that she intends to invest in her agricultural activities. Today, Mary is a single mother: She separated from her first husband and her second husband has passed away. Of her six children, two sons moved to Congo to start a business selling clothes. The other children either study or help their mother with domestic work and the sorghum business. The main income in the household comes from Mary's activities. It is supplemented by occasional remittances from her sons.
\end{abstract}

(Interview with Mary, 8 May 2014)

\title{
6. Reconstructing Livelihoods after Multiple Displacements
}

The lives of people in this village have been impacted by repeated displacements caused by Rwanda's conflict history, its resettlement policy and more recently the government's environmental conservation policies. Each time they have been uprooted from their productive environment. The survey and the focus group discussions revealed that most households in this village are old caseload refugees that returned from the DRC. They share a history of displacement and enforced resettlements, for some dating back to 1959 as the stories above illustrate. The household survey shows that apart from younger children who were born in the village, all the respondents had moved there from elsewhere.

All of the 10 respondents spent the majority of their childhood and early adulthood in the DRC, where their parents fled with their households in the 1950's. In the DRC many had managed to build a sustainable livelihood thanks to the abundance of farmland. Six of the ten respondents recalled their households owned large herds of cows - an animal that has a very symbolic role in Rwandan history and culture. Despite their position as refugee having fled violent conflict, and many living in refugee camps, through access to natural capital, households were able to accumulate financial capital and increase the wellbeing of their families. In 1994, these old caseload refugees returned to Rwanda, re-entering the country in the footsteps of the RPF (the Rwandan Patriotic Front-the current ruling political party in Rwanda). People left all their possessions behind to rebuild a life in Rwanda. Some opted to settle in small trading centres, while others occupied the houses of people who had fled the country during the genocide. Others were temporarily accommodated in refugee camps. In the north-western region, the 1996-1998 civil war again disrupted their fragile livelihoods. Livestock were killed, and houses were burned down, and the feeling of great insecurity prevented people from farming their plots of land or looking for income generating activities. Coming 'home' to a situation of unsafety and uncertainty, restricted people's ability to re-accumulate capital and rebuild their livelihoods to their previous state. After this period of protracted displacement, the households 
in this village were given plots of land in the Gishwati area, where they were allowed to live and farm, due to their status as old caseload refugees. This process of post-conflict resettlement planning gave people again access to natural capital in the form of land, which has been central to their livelihood strategies. Households were able to reconstruct their livelihoods and accumulate different capitals. The very fertile plots allowed many to build a very profitable livelihood based on farming and the stability of their situation allowed them to build stronger social networks. As the stories illustrate, this is a time all respondents associate with increasing incomes and wellbeing. Yet again, because the government prohibited farming in the Gishwati area as one of its 'climate change adaptation interventions', people lost the productive resources crucial to their livelihoods, and they were forcibly resettled under the villagization policy. As part of this intervention, the surrounding plots of land were confiscated for redistribution among the residents. This lengthy process caused many to lose their main source of income for up to 10 years, and forced people to run down their assets accumulated during the previous years and become more inventive in their livelihood strategies. As a consequence, people had to turn to the uncertainty of wage labour or even move to refugee camps in Huye, Nyamagabe, Gicyumbe or Karongi, or go back to the DRC (focus group discussion with male heads of household, 2 May 2014; focus group discussion with female heads of household, 2 May 2014). People were asked to choose between grazing land or arable land, which determined their future livelihood. As people in the village reported, those who had 10 or more cows could get a large plot of grazing land; if not, they had to settle for arable land (focus group discussion with male heads of household, 2 May 2014; focus group discussion with female heads of household, 2 May 2014). Celestin had lost almost all his cows, and so he could only make a claim on arable land. Today, he has three cows and he cannot have more, because he does not have more grazing land. As very symbolic assets in Rwanda, the selling of his cows to survive this period was a particularly sensitive issue for Gaspard. Since many lost their cattle as a consequence of these repeated events dispossessing them of their assets, the majority of people had to opt for arable land. This led to people owning very small plots, often terraces of barely eight by two metres.

Ownership of and access to resources are crucial for recovering one's livelihood trajectories in the wake of exposure to shocks and stresses. The stories illustrate the crucial role of access to natural capital for these households' livelihoods, as well as its importance in Rwanda's post-conflict reconstruction. The stories show that as long as people had access to land, this protective factor enabled them to cope and to recover their livelihood activities of pastoralism and farming. Since the last forced displacement from Gishwati forest deprived them from their productive resources, people have had to become more creative and versatile to reconstruct their livelihoods. The historical livelihood activities of the households in this village has historically been based on farming or livestock activities, the livelihood histories of the respondents show increasingly diversified livelihoods strategies, for example by engaging in extra activities, such as wage labour or small businesses. Historical livelihood trajectories, in which rapid adaptive strategies were often needed to cope with repeated relocations, can affect the ability to quickly adapt and recover. For some, it is just another ordeal they have to endure, as they have done so many times before. Eliphace, a 63-year-old father of 10 children whose story shows many similarities to that of Gaspard, put it this way: "Even the poor people here can adopt and survive. We all hardly survived during the last five years, without land and job opportunities." (Interview with Eliphace, 13 May 2014). He has always been a farmer, but since the plots they received in 2014 were too small to produce enough food for his family, he was forced to diversify his income-generating activities and engage in some minor business activities, such as selling milk and cheese, to survive. For others, such protective factors as entrepreneurial skills make them more resilient, enhancing their adaptive capacity; an example is Mary, the woman with a sorghum beer business. At the same time, these historical trajectories also influence people's adaptive capacity in a more negative way. When discussing the livelihood opportunities available to people today during the focus group discussion, the women pointed out that because most of the men in the village are generally used to 
taking care of livestock, there is little else that they can do. Natural assets needed to be substituted by other types, mainly by social or human capital, to which not everyone has equal access.

The individual itineraries in the boxes above demonstrate how similar trajectories of displacement can induce varied trajectories in terms of livelihood reconstruction. It is often not just the spatial dislocation that poses the biggest challenge to people's adaptive capacity. The analysis revealed that age also plays a role in people's ability to get up again and construct or reconstruct sustainable livelihoods, while also having to adjust to a rapidly transforming society in terms of economic, spatial and social configurations. Households with younger members show more creativity and capacity to combine different capitals into (new) viable livelihood strategies. The story of Gaspard illustrates that at a certain age people lack the physical capacity (or human capital) to rebuild what they had and they have to rely more on their social capital. At the other end of the spectrum, the younger generation also have their own way of dealing with adverse circumstances. During the focus group discussion, young boys and girls reflected on the activities that were available to them in order to start building their own lives and families. Since some of them had been working for a government terracing project, upcoming development projects often formed the basis of their hopes for employment. There were rumours of village upgrading programmes and the reforestation of Gishwati forest.

"If the situation stays the same as today, this village cannot provide a future for young people. We need a new infrastructural project or a market, otherwise young people will leave." (Focus group discussion with youths, 2 May 2014).

Local wage labour is often not given to them, as many do not consider youths to be serious workers. Since their parents already struggle with land scarcity, many have given up hope of ever possessing their own land for farming in or around this village. As the above quotation suggests, many youngsters consider looking for opportunities elsewhere and move away to places closer to the main road, trade centres or even the capital, Kigali. Others indicated that they would rather move to Congo, Uganda or Tanzania, where land is still available.

It is clear that some households have limited access to capital in comparison with others, hence less adaptive capacity. The livelihood-mobility histories showed that for all households, this latest displacement has severely altered their livelihoods and their economic situation. Being deprived of their familiar productive resources, they struggle to rebuild a sustainable and satisfying livelihood. More access to human or social capital, having resident children of working age and/or an extra skillset, slightly increased a households' adaptive capacity.

\section{7. "You May Not Have Money, But You Have Legs to Move"}

In the present research, specific attention was paid to the mobility patterns of the households in the sample. In addition to being forced to move to new places, these displacements also elicit other forms of mobility. Not only livelihood activities and income but also the mobility patterns of the households in this village had changed. The interviews and focus group discussions revealed that the mobility practices of the households in this village were perceived to have changed a lot over the previous years. The main reason given for this change was a deteriorating economic situation. The loss of land was the most important cause of a reduced income. When they were physically isolated from their previous livelihoods and productive resources, many respondents felt the need for mobility. The men saw the biggest change in mobility when they replaced the walks to their plots in Gishwati forest with trips to the small centres of Kora and Jenda in search of alternative sources of income, because their farmland, productivity and income had decreased (Focus group discussion with male heads of household, 2 May 2014). As one woman during the focus group discussion said: "When you are ready to die, you go away to look for wage labour." (Focus group discussion with female heads of household, 2 May 2014). In this context, by 'ready to die' she meant when you do not have food for several days and do not own land or any other property, you have no other choice. Looking at the baseline survey, most of the movements were circular in character with people moving on a daily or 
weekly basis. This was further confirmed by the more in-depth household mobility histories, as many mobile household members moved to other rural destinations where they farm, trade milk and cheese or find casual wage labour. Although mobility can also be viewed as a strategy for accumulation, in this village it is clear that in most cases it is a way spreading risks or a survival mechanism when other opportunities are not locally available. Human capital, in the form of mobile household members, proved important to the adaptive capacity of households when coping with a vulnerability context of displacement or resettlement.

Despite what the title of this section suggests, not all household members have 'legs to move' (Quotation from Focus Group Discussion with Male Heads of Household, 2 May 2014). Often the mobility of household members puts an extra burden on those who are less mobile, because of their labour and social responsibilities. During the focus group discussion, some women said that they used to move around working for temporary construction projects, such as health centres or terracing. However, others said that as they are widows and the heads of household, they cannot move that easily as they are responsible for both household duties and providing an income. Furthermore, the elderly and the sick are not able to move around in search of an income, and they often have to depend on their children. Gaspard's household is an example of this, as illustrated above. Such households often organise themselves in such a way as to benefit from opportunities that are available in different locations along the rural-urban continuum, pooling their income, as I addressed in previous publications on rural livelihoods and mobility in Rwanda [28,29]. As the story of Gaspard suggests, several households had expanded their areas of operation by engaging in livelihood activities and social relations outside of their places of residence. Furthermore, Celestin has a son who lives in Kigali and a daughter who moves to Musanze for extensive periods of time to stay with family. Having a social network or family extending over the rural-urban continuum is often crucial for this type of arrangement. When discussing multi-local strategies during the focus group, one woman pointed out that also here their history of displacement plays a role. She does not have any family members in Rwanda to whom she can send her daughter, so she stays around the house, which is a problem that many 1959 returnees are facing. Nevertheless, it is obvious that physical mobility forms an important part of the lives and livelihoods of many households in this village. As part of the historical livelihood trajectories of these households, intensified mobility flows and circulations are shaping this village and its possible development path. Real articulations of social and material relations between various spatial scales at the household level are interactions through which place and space are constantly constructed, and local development can no longer be regarded in the context of one fixed setting [30].

\section{Conclusions}

The present research investigated how repeated displacement and resettlement has affected people's lives and livelihood trajectories in Rwanda and the importance of various capitals they employ when adapting to adverse circumstances. To this purpose, an analysis was made of the effects of multiple and repeated displacements on rural households' adaptive capacity in one particular case study in the north-western region of Rwanda. These households have faced forced displacements dating back to 1959, caused by eruptions of violent conflict, resettlement policies, and environmental hazards or conservation measures. Although the problem explored here is very local in terms of lived experience, the findings can have a broader relevance for the study on the impact of involuntary displacement on livelihoods. A longitudinal study following these households throughout the experiences of displacement could indicate the exact assets and capitals of the households, how they have been employed towards reconstructing their livelihoods and their livelihood outcomes. However, since this is a practical challenge that is difficult to overcome, a qualitative approach focusing on the historical livelihood trajectories of the households affected proves to be a valuable method. This could be further explored and developed in future research on the effects of displacement on people's livelihood and adaptive capacity. 
The households in this case study are operating in a context of vulnerability characterised by repeated displacements, within which they do or do not have access to certain assets or capitals. Depending on the prevailing social, institutional and policy environment these assets gain or lose value and weight, shaping the strategies employed by the households to repeatedly reconstruct their livelihoods. The findings show that although the households in this case study share a specific history of repeated displacements, the historical livelihood trajectories of individual households seem to matter when looking at the capacity of households to deal with or recover from these situations of stress and shock. While they all have to cope with similar risk factors, namely being deprived of their productive resources, such as land and livestock, protective factors at the individual household level often determined people's adaptive capacity.

The literature on the effects of displacement on people's livelihood have illustrated how deprivation of crucial assets, such as natural capital and social capital lead to an overall decline in living conditions and wellbeing $[6,9,13,14]$. This suggests that in case of multiple or repeated displacement, affected households and individuals might end up in a downward spiral, having to continuously re-accumulate capital and livelihood strategies. The empirical evidence shows that the livelihood outcomes of an event of displacement or resettlement depend on the vulnerability context, as well as the structure determining access to crucial resources. In line with previous studies on the effects of displacement on livelihoods in the developing world [11], the findings in this case study show that the ability of the displaced to adjust to their new surroundings is largely influenced by their access to natural capital. However, not all displacements that the households in this case study experienced necessarily had a negative livelihood outcome. Where one capital, in this case natural capital like land and livestock, was abundant households managed to reconstruct their livelihoods with outcomes often surpassing the previous state. Land and other natural resources are an important asset in the historical livelihood trajectories of the households in this case study. It is a crucial and symbolic issue in Rwanda's post-conflict reconstruction, as land governance has become a challenging issue in a landscape of multiple groups of refugees, returnees and IDPs with different claims to the land. The policies managing the distribution of land, which stand central to the Rwandan government's post-conflict agenda, are important processes influencing and managing the access of people to natural capital.

Looking at the interplay between various livelihood capitals substituting the loss of natural resources, two types were found to be crucial to people's adaptive capacity. Social capital in the form of horizontal connections, family support through remittances and community solidarity, and the use of human capital in the form of entrepreneurial skills and household members able to work. Even though these two capitals prove important to the capacity of in the households to adapt, the successive loss of the productive resources in combination with the changing social and economic conditions in which they have to secure an income diminishes the ability of many households to keep employing these capitals to reconstruct a sustainable livelihood. Often not able to rise above the level of survival forces them to become increasingly creative and flexible in their coping strategies. This is another interpretation and illustration of what Hammar [3] calls the paradox of displacement, entailing both experiences of dislocation and movement, destruction, as well as creativity. In this case study, the use of mobility as an extra asset is one of the main expressions of such creativity. Although mobility can also be viewed as a strategy for accumulation, in this case study it is clear for the majority it is a way of spreading risks or a survival mechanism when other opportunities are not locally available. Some have attempted to resolve their problematic positioning through multi-local livelihoods, which combine access to nonlocal income through temporary migration. It is often the younger household members who engage in these different patterns of mobility. Through mobile and multi-local livelihood strategies, many households in this village rely on geographically stretched social networks as an important asset. The stories of many respondents showed that having connections in other places is vital, as they rely on the help they get from children who live elsewhere. It is mainly youths who engage in the various patterns of mobility and migration that have become part of households' livelihoods. 
Responses to repeated displacements and involuntary resettlements, paired with the successive loss of productive resources, need to acknowledge that the reconstruction of livelihoods does not always take place in fixed settings, but is shaped by the way people are attached to and participate in networks. When access to natural capital cannot be guaranteed or is not sufficient, supporting structures to facilitate the employment of other capitals and assets to promote diversification are crucial.

Funding: This research was funded by the European Union under the 7th Research Framework Programme (theme SSH) Grant Agreement number 290732. More information can be found at: http:/ / rurbanafrica.ku.dk/.

Conflicts of Interest: The author declares no conflict of interest.

\section{References}

1. IDMC. Africa Report on Internal Displacement. Available online: http:/ / www.internal-displacement.org/ publications /2017-africa-report-on-internal-displacement (accessed on 7 June 2017).

2. Zoomers, A. Introduction: Rushing for land: Equitable and sustainable development in Africa, Asia and Latin America. Development 2011, 54, 12-20. [CrossRef]

3. Hammar, A. Displacement Economies in Africa: Paradoxes of Crisis and Creativity; Zed Books: London, UK, 2014; ISBN 9781780324883.

4. Corbin, J.N.; Hall, J.C. Resettlement post conflict: Risk and protective factors and resilience among women in northern Uganda. Int. Soc. Work 2018. [CrossRef]

5. Lisher, S.K. Causes and consequences of conflict-induced displacement. Civ. Wars 2007, 9, 142-155. [CrossRef]

6. Potts, D. Displacement and livelihoods: The longer term impacts of Operation Murambatsvina. In The Hidden Dimensions of Operation Murambatsvina in Zimbabwe; Vambe, M., Ed.; Weaver Press: Pretoria, South Africa, 2008; pp. 53-64, ISBN 9781779220714.

7. Wayessa, G.O.; Nygren, A. Whose Decisions, Whose Livelihoods? Resettlement and Environmental Justice in Ethiopia. Soc. Nat. Resour. 2016, 29, 387-402. [CrossRef]

8. Arnall, A.; Thomas, D.S.; Twyman, C.; Liverman, D. Flooding, resettlement, and change in livelihoods: Evidence from rural Mozambique. Disasters 2013, 37, 468-488. [CrossRef] [PubMed]

9. Carney, D. Sustainable Rural Livelihoods: What Contribution Can We Make? DDFID: London, UK, 1998; ISBN 9781861920829.

10. Scoones, I. Sustainable Rural Livelihoods: A Framework for Analysis; IDS Working Paper 72; IDS: Brighton, UK, 1998.

11. Jaysawal, N.; Saha, S. Impact of displacement on livelihood: A case study of Odisha. Community Dev. J. 2018, 53, 136-154. [CrossRef]

12. Rowan, M. Aligning resettlement planning and livelihood restoration with social impact assessment: A practitioner perspective. Impact Assess. Proj. Apprais. 2017, 35, 81-93. [CrossRef]

13. O'Reilly, C. Household Recovery from Internal Displacement in Northern Uganda. World Dev. 2015, 76, 203-215. [CrossRef]

14. Hong, P.Y.P.; Singh, S.; Ramic, J. Development-induced impoverishment among involuntarily displaced populations. J. Comp. Soc. Welf. 2009, 25, 221-238. [CrossRef]

15. Newbury, D. Returning Refugees: Four Historical Patterns of "Coming Home" to Rwanda. Comp. Study Soc. Hist. 2005, 47, 252-285. [CrossRef]

16. Kiboro, C.N. Influence of Social Capital on Livelihood Outcomes for the Internally Displaced Persons in Kenya: A Social Capital Approach. Eur. Sci. J. 2017, 13, 266-280. [CrossRef]

17. Kesmaecker-Wissing, M.; Pagot, A. Driven Apart How Repeated Displacement Changes Family Dynamics in Eastern DRC; The Internal Displacement Monitoring Centre: Geneva, Switzerland, 2015.

18. Beytrison, F.; Kalis, O. Repeated displacement in eastern DRC. Forced Migr. Rev. 2013, 43, 22-23.

19. Kabra, A. Displacement, resettlement, and livelihood restoration: Safeguard standards in practice. Dev. Pract. 2018, 28, 269-279. [CrossRef]

20. DFID. Defining Disaster Resilience: A DFID Approach Paper. London, UK, 2011. Available online: https://www.fsnnetwork.org/sites/default/files/dfid_defining_disaster_resilience.pdf (accessed on 20 June 2018). 
21. Speranza, C.I.; Wiesmann, U.; Rist, S. An indicator framework for assessing livelihood resilience in the context of social-ecological dynamics. Glob. Environ. Chang. 2014, 28, 109-119. [CrossRef]

22. Klein, R.J.T.; Huq, S. Climate Change, Adaptive Capacity and Development; Imperial College Press: London, UK, 2003.

23. Thulstrup, A.W. Livelihood Resilience and Adaptive Capacity: Tracing Changes in Household Access to Capital in Central Vietnam. World Dev. 2015, 74, 352-362. [CrossRef]

24. Gebauer, C.; Martin, D. Adaptation to climate change and resettlement in Rwanda. Area 2015, 47, 97-104. [CrossRef]

25. Hilhorst, D.J.M.; Leeuwen, M.V. Imidugudu, Villagisation in Rwanda: A Case of Emergency Development? Research Report Disaster Sites, No 2; Wageningen Disaster Studies: Wageningen, The Netherlands, 1999.

26. Norwegian Refugee Council/Internal Displacement Monitoring Centre (NRC/IDMC). Profile of Internal Displacement: Rwanda, 8 July 2005. Available online: http:/ / www.refworld.org/docid/3f4912fa4.html (accessed on 30 May 2018).

27. BBC. Rwanda Landslides after Heavy Rain Bring 2018 Death Toll to 200. BBC News. Available online: http:/ / www.bbc.com/news/world-africa-44031799 (accessed on 30 May 2018).

28. Cottyn, I.; Nijenhuis, G. Livelihoods on the Move? Diversification and Mobility in the Changing Rural Context of North-West Rwanda. Trialog 116/117 2016, 1-2, 22-27.

29. Steel, G.; Cottyn, I.; Lindert, P. New Connections-New Dependencies: Spatial and Digital Flows in sub-Saharan African Livelihoods. In Livelihoods and Development. New Perspectives; de Haan, L., Ed.; Brill: Leiden, The Netherlands, 2017; pp. 148-167, ISBN 9789004342255.

30. Zoomers, A.; Leung, M.; Westen, G. Local development in the context of global migration and the global land rush: The need for a conceptual update. Geogr. Compass 2016, 10, 56-66. [CrossRef]

(C) 2018 by the author. Licensee MDPI, Basel, Switzerland. This article is an open access article distributed under the terms and conditions of the Creative Commons Attribution (CC BY) license (http:/ / creativecommons.org/licenses/by/4.0/). 